Portland State University

PDXScholar

\title{
Marine Debris and Human Health: An Exposure Pathway of POPs?
}

Katie Conlon

Portland State University, conlon@pdx.edu

Follow this and additional works at: https://pdxscholar.library.pdx.edu/usp_fac

Part of the Environmental Health and Protection Commons, and the Urban Studies and Planning Commons

Let us know how access to this document benefits you.

\section{Citation Details}

Conlon, K. (2021), Marine Debris and Human Health: An Exposure Pathway of POPs?. Environ Toxicol Chem. Accepted Author Manuscript. https://doi.org/10.1002/etc.5186

This Post-Print is brought to you for free and open access. It has been accepted for inclusion in Urban Studies and Planning Faculty Publications and Presentations by an authorized administrator of PDXScholar. Please contact us if we can make this document more accessible: pdxscholar@pdx.edu. 
Katie Conlon ORCID iD: 0000-0002-7454-2705

21-00288

Critical Perspectives

K. Conlon

Marine debris and human health

Marine Debris and Human Health: An Exposure Pathway of POPs?

Dr. Katie Conlon ${ }^{*}$

Portland State University, Portland, OR, USA

(Submitted 25 April 2021; Accepted 02 August 2021)

Abstract: Although there are not any direct studies linking persistent organic pollutants (POPs) accumulated on marine debris to human health, there are numerous studies showing human health impacts from repeated and high level POP exposure, as well as studies that show POPs accumulate on plastic debris in the marine environment. With this knowledge, there is a need for greater awareness of the risks of POP exposure for those who handle marine debris regularly, especially in contexts of higher exposure such as those working in marine debris concentrated areas. Amongst the scientific community, understanding of the exposure risk might be high, but others who handle marine debris, for instance citizens groups in the global south, are not necessarily aware of this exposure pathway. Moreover, global consumers who are marketed 'ocean plastics' upcycled products are also not aware of potential POP exposure. Before marine plastics are accepted into the upcycled economy, these risks warrant further examination. This is a

This article has been accepted for publication and undergone full peer review but has not been through the copyediting, typesetting, pagination and proofreading process, which may lead to differences between this version and the Version of Record. Please cite this article as doi: 10.1002/etc.5186.

This article is protected by copyright. All rights reserved. 
perspectives piece that aims to draw awareness to these emergent POP exposure pathways and considerations regarding marine plastic pollution.

Keywords: bioaccumulation, contaminants, environmental transport, hazard/risk assessment, marine plastics

*Address correspondence to Published online XXXX 2021 in Wiley Online Library (www.wileyonlinelibrary.com). DOI: $10.1002 /$ etc.xxxx

\section{Introduction}

Although there are not any direct studies linking persistent organic pollutants (POPs) accumulated on marine debris to human health, there are numerous studies showing human health impacts from repeated and high level POP exposure. The consideration of marine debris and human health especially relates to researchers and activists who regularly work with debris from the ocean gyres, as well as debris coming directly from the gyres, such as in places like Hawaii, where plastic has been in the environment longer and has adsorbed more pollutants.

Marine debris impacts on marine health is well established (Agamuthu et al., 2019; Andrady, 2011; Cole et al., 2011; Lusher et al., 2013; Rochman et al., 2016). One point of universal action on marine debris has been cleanups, and over the past several decades, researchers, activists, and concerned citizens around the globe have made efforts to collect, document, and dispose of marine debris. For instance, a recent global cleanup by Break Free From Plastic worked with 70,000 volunteers across 50 countries (Break Free From Plastic, 2020); and at world cleanup day, millions of people participate from 180 countries (World Clean Up Day, 2020). However, in the collection of all of this 
plastic, the link between persistent organic pollutants (POPs) and the health of those with repeated exposure collecting marine debris has been overlooked.

POPs and longevity

POPs can be transported by wind and water, and can be found at great distances from their point of origin, making them a global issue (EPA, 2020). POPs include substances like pesticides (i.e. DDT), industrial chemicals (i.e. PCBs) and by-products from production processes (i.e. dioxins) which remain for decades in the environment. To limit POPs, the Stockholm Convention on POPs specifically targets certain POPs due to their studied human and environmental toxicity, bioaccumulation, and potential for long range environmental transport. Their list continues to evolve as more substances are found to be detrimental to health (Wang et al., 2009). However, due to the political nature of banning chemicals, certain POPs are not on the ban list and are still being produced and adding to global chemical loads, and even used as additives in plastics manufacturing (SPC/RAC, 2020).

POPs in the marine environment

In the marine environment, Rios et al (2007) report that marine debris trap POPs, and their research indicates this to be consistent with POPs accumulation on debris from several sites (the Pacific Gyre, Hawaii, Mexico). In 2010, Rios et al. followed up with more research on POPs, where they continued to find PCBs, PAHs, and pesticides on plastics in the north Pacific Gyre. "This is the first study to show that floating plastic debris from the NPG is an important pollutant extraction agent. The plastic serves to adsorb and accumulate persistent pollutants from the seawater. In this way, the floating plastic debris acts as like the solid particles that sink into marine sediments with the 
exception that these particles float and stay within reach of many marine creatures” (2235). Essentially, these studies show that marine debris acts as a sponge to POPs in the surrounding environment, and thus the plastic debris is shown to have high concentrations of POPs present on their surfaces. In the north Atlantic gyre and in Indonesia, Bouhroum et al. (2019) also report levels of POPs that are detrimental for marine health, and further concern for marine debris ingestion and this toxicity moving up the food chain. Once this debris reaches a shoreline, the accumulated POPs and PAHs (polycyclic aromatic hydrocarbons) are shown to still be present on the surface of marine debris, such as a study confirmed in San Diego (Van et al., 2012).

One step further up the marine food chain, researchers have reported the bioaccumulation of POPs in deep ocean fauna (Jamieson et al., 2017). Another study shows POPs in turtles that have ingested marine debris plastic (Clukey et al., 2018). Hermabessiere et al. (2017) report that microplastics might also be a source of some of the harmful toxic chemicals in the environment, as plastics leach inherent additives that include endocrine disruptors, phthalates, BPA, and flame retardants.

POP exposure and human health

Considering human health impacts, research indicates that mere exposure to POPs can be a hazard to human health (rather than ingestion as shown with animals). Studies of POP exposure report a link between occupational exposure ${ }^{1}$ to POPs and cardiovascular and endocrine disrupting health issues (Lind and Lind, 2012). Another report shows POPs linked to, "cancer, impaired neurobehavioral and immune function, reduced sperm count, diabetes, etc.” (Damstra et al., 2002). And, a survey of research on POP exposure

\footnotetext{
${ }^{1}$ Which could be comparable to someone who regularly picks up marine debris as part of their research or as local environmental activism.
}

This article is protected by copyright. All rights reserved. 
shows, "growing evidence that some POPs act as endocrine disrupters, mimicking hormones by binding to or blocking hormone receptors.” (Abelsohn et al., 2002). Moreover, studies have linked inherent chemicals in plastic, plasticizers not yet banned, to endocrine disruption and the decline in reproductive health in developed countries over the past 60 years (Colborn et al., 1993; Freinkel, 2011; Maffini et al., 2006; Rolland et al., 2012).

Invisible hazards in cleanups

Currently there is no data on potential impacts of humans exposed to POP contaminated marine debris in cleanups. However, what should marine debris cleanups do in the meantime to keep everyone safe and healthy? Use precaution, and use gloves to limit skin exposure to this material. Scientists know the risks of POP exposure; however, others who clean-up marine pollution may not. For instance, concerned citizens who pick up marine debris with their bare hands, trying to do a 'good deed' by cleaning up the beach; and those in the global south, in areas of greatest beach pollution and minimal health protocols, these groups are potentially unsuspecting of any health consequences (countries with the greatest amount of marine debris are located in Asia and include China, Indonesia, the Philippines, and Vietnam (Jambeck et al., 2015)). Pathways of POPs through marine plastic pollution recycling and upcycling Another consideration is what to do with marine debris after collection. Currently, there is a buzz around recovery of marine debris and manufacturing this debris into new products, turning "trash into value" as an environmental and economic solution to marine debris (Plastics Technology, 2018); this recovery solution was also promoted at the $6^{\text {th }}$ International Marine Debris Conference (Sixth International Marine Debris Conference, 
2021). With no recognition of potential POP contamination, 'ocean plastics' are finding their way into the production of numerous global brands (Burke, 2019). Examples of this trash to treasure marine debris solutions narrative includes for instance, marine debris into shoes and sportswear (Morgan, 2019), and sunglasses (The Ocean Cleanup, 2020). However, these new applications could also be pathways for continued POP exposure. Moving forward for safe marine debris collection

Even though recycling and/or upcycling seems like the 'environmental' choice for handling marine debris, sanitary landfilling is the best option we have at this point. Incineration is not desirable as it releases harmful dioxins (also a form of POPs) which are carcinogenic to the surrounding community (GAIA, 2018). Also, depending on the context, some marine debris can be coming into the marine environment almost directly from a surrounding community, for instance in places where waste is disposed of in waterways and at sea. Although this debris has not been out at sea accumulating pollutants for long, this material should also be handled with caution, as recent reports highlight the harms of toxicity in the additives found in everyday plastic products, before any POP adsorption (SPC/RAC, 2020).

Ultimately, awareness of the hazards of POPs and human health should extend past researchers, to the communities of concerned citizens and plastic activists around the globe. With this knowledge, researchers and citizens can enact caution when handling and disposing of marine debris potentially contaminated with high levels of POPs; as well as advocate for more attention to the human and environmental health impacts of marine debris. This also represents a research opportunity, to fill in the gap between POP

This article is protected by copyright. All rights reserved. 
exposure (and other plastic additives) and human health impacts for those working in this field.

Data availability statement—Data, associated metadata, and calculation tools are available from the corresponding author (conlon@pdx.edu).

\section{References}

Abelsohn, A., Gibson, B. L., Sanborn, M. D., \& Weir, E. (2002). Identifying and managing adverse environmental health effects: 5. Persistent organic pollutants. Cmaj, 166(12), 1549-1554.

Agamuthu, P., Mehran, S. B., Norkhairah, A., \& Norkhairiyah, A. (2019). Marine debris: A review of impacts and global initiatives. Waste Management \& Research, 37(10), 9871002.

Andrady, A. L. (2011). Microplastics in the marine environment. Marine pollution bulletin, 62(8), 1596-1605.

Bouhroum, R., Boulkamh, A., Asia, L., Lebarillier, S., Ter Halle, A., Syakti, A. D.,... \& Wong-Wah-Chung, P. (2019). Concentrations and fingerprints of PAHs and PCBs adsorbed onto marine plastic debris from the Indonesian Cilacap coast and theNorth Atlantic gyre. Regional Studies in Marine Science, 29, 100611.

Break Free From Plastic. (2020). The Brand Audit Report. Break Free From Plastic. Retrieved on Dec., 30, 2020, from:

https://www.breakfreefromplastic.org/globalbrandauditreport2020/

Burke, O. (May 6, 2019). 11 ocean-friendly companies like Patagonia and Adidas that are removing plastic from our seas and transforming it into cool new products. Business Insider. Retreived on March 11, 2021, from: https://www.businessinsider.in/thelife/11- 
ocean-friendly-companies-like-patagonia-and-adidas-that-are-removing-plastic-from-ourseas-and-transforming-it-into-cool-new-products/articleshow/69206906.cms

Clukey, K. E., Lepczyk, C. A., Balazs, G. H., Work, T. M., Li, Q. X., Bachman, M. J., \& Lynch, J. M. (2018). Persistent organic pollutants in fat of three species of Pacific pelagic longline caught sea turtles: Accumulation in relation to ingested plastic marine debris. Science of the Total Environment, 610, 402-411.

Colborn, T., Vom Saal, F. S., and Soto, A. M. (1993). Developmental effects of endocrine-disrupting chemicals in wildlife and humans. Environmental Health Perspectives, 101(5), 378-384.

Cole, M., Lindeque, P., Halsband, C., \& Galloway, T. S. (2011). Microplastics as contaminants in the marine environment: a review. Marine pollution bulletin, 62(12), 2588-2597.

Damstra, T., Page, S. W., Herrman, J. L., \& Meredith, T. (2002). Persistent organic pollutants: potential health effects?. Journal of Epidemiology \& Community Health, 56(11), 824-825.

EPA. (2021). Persistent Organic Pollutants: Global issue, global response. EPA. Retrieved on Feb., 26, 2021, from: https://www.epa.gov/internationalcooperation/persistent-organic-pollutants-global-issue-global-response Freinkel, S. (2011). Plastic: a toxic love story. Melbourne: Text Publishing. GAIA. (2018). Facts About “Waste-To-Energy” Incinerators. Global Alliance for Incinerator Alternatives (GAIA). Retrieved on November 10, 2019, from: www.noburn.org

This article is protected by copyright. All rights reserved. 
Hermabessiere, L., Dehaut, A., Paul-Pont, I., Lacroix, C., Jezequel, R., Soudant, P., \& Duflos, G. (2017). Occurrence and effects of plastic additives on marine environments and organisms: a review. Chemosphere, 182, 781-793.

Jambeck, J.R., Geyer, R., Wilcox, C., Siegler, T.R., Perryman, M., Andrady, A., Narayan, R. and Law, K.L. (2015). Plastic waste inputs from land into the ocean. Science, 347(6223), 768-771.

Jamieson, A. J., Malkocs, T., Piertney, S. B., Fujii, T., \& Zhang, Z. (2017).

Bioaccumulation of persistent organic pollutants in the deepest ocean fauna. Nature ecology \& evolution, 1(3), 1-4.

Lind, L., \& Lind, P. M. (2012). Can persistent organic pollutants and plastic-associated chemicals cause cardiovascular disease?. Journal of internal medicine, 271(6), 537-553. Lusher, A. L., Mchugh, M., \& Thompson, R. C. (2013). Occurrence of microplastics in the gastrointestinal tract of pelagic and demersal fish from the English Channel. Marine pollution bulletin, 67(1-2), 94-99.

Maffini, M. V., Rubin, B. S., Sonnenschein, C., and Soto, A. M. (2006). Endocrine disruptors and reproductive health: The case of bisphenol-A. Molecular and Cellular Endocrinology, 254-255, 179-186.

Morgan, C. (Sept., 2, 2019). Adidas is turning plastic ocean waste into sneakers and sportswear. Business Insider. Retrieved on Feb., 26, 2021, from:

https://www.ptonline.com/articles/trash-as-value-turning-ocean-waste-into-viableproducts

This article is protected by copyright. All rights reserved. 
Plastics Technology. (2018). Trash as Value: Turning Ocean Waste into Viable Products. REtreived on Feb., 26, 2021, from: https://www.ptonline.com/articles/trash-as-valueturning-ocean-waste-into-viable-products

Rios, L. M., Jones, P. R., Moore, C., \& Narayan, U. V. (2010). Quantitation of persistent organic pollutants adsorbed on plastic debris from the Northern Pacific Gyre's “eastern garbage patch”. Journal of Environmental Monitoring, 12(12), 2226-2236.

Rios, L. M., Moore, C., \& Jones, P. R. (2007). Persistent organic pollutants carried by synthetic polymers in the ocean environment. Marine pollution bulletin, 54(8), 12301237.

Rochman, C. M., Browne, M. A., Underwood, A. J., Van Franeker, J. A., Thompson, R. C., \& Amaral-Zettler, L. A. (2016). The ecological impacts of marine debris: unraveling the demonstrated evidence from what is perceived. Ecology, 97(2), 302-312.

Rolland, M., Le Moal, J., Wagner, V., Royère, D., and De Mouzon, J. (2012). Decline in semen concentration and morphology in a sample of 26,609 men close to general population between 1989 and 2005 in France. Human Reproduction, 28(2), 462-470.

Sixth International Marine Debris Conference. (2021). Bringing Value to Marine Debris. Retrieved on Feb. 26, 2021, from:

https://internationalmarinedebrisconference.org/index.php/bringing-value-to-marinedebris/

Sustainable Consumption and Production Regional Activity Center (SCP/RAC). (2020). Plastic's toxic additives and the circular economy. SCP/RAC. Retrieved on Oct. 8, 2020, from: http://www.cprac.org/en/news-archive/general/toxic-additives-in-plastics-hiddenhazards-linked-to-common-plastic-products

This article is protected by copyright. All rights reserved. 
The Ocean Cleanup. (Oct., 24, 2020). Turning trash into treasure: The Ocean Cleanup sunglasses. The Ocean Cleanup. Retrieved on Feb., 26, 2021, from:

https://www.ptonline.com/articles/trash-as-value-turning-ocean-waste-into-viableproducts

Van, A., Rochman, C. M., Flores, E. M., Hill, K. L., Vargas, E., Vargas, S. A., \& Hoh, E. (2012). Persistent organic pollutants in plastic marine debris found on beaches in San Diego, California. Chemosphere, 86(3), 258-263.

Wang, T., Wang, Y., Liao, C., Cai, Y., \& Jiang, G. (2009). Perspectives on the inclusion of perfluorooctane sulfonate into the Stockholm convention on persistent organic pollutants.

World Clean Up Day. (2020). Home. World Clean Up Day. Retrieved on Feb., 26, 2021, from: https://www.worldcleanupday.org/

This article is protected by copyright. All rights reserved. 